\title{
Human intracerebroventricular (ICV) injection of autologous, non-engineered, adipose-derived stromal vascular fraction (ADSVF) for neurodegenerative disorders: results of a 3-year phase 1 study of 113 injections in 31 patients
}

\author{
Christopher Duma ${ }^{1}\left[\right.$ - Oleg Kopyov ${ }^{1} \cdot$ Alex Kopyov $^{1} \cdot$ Mark Berman $^{2} \cdot$ Elliot Lander $^{2} \cdot$ Michael Elam $^{2}$. \\ Michael Arata ${ }^{2}$. David Weiland ${ }^{3} \cdot$ Ruslana Cannell $^{4} \cdot$ Chad Caraway $^{4} \cdot$ Sean Berman ${ }^{2} \cdot$ Kristin Scord $^{1} \cdot$ Lian Stemler $^{1}$. \\ Karlyssa Chung ${ }^{1}$ - Samuel Khoudari ${ }^{1} \cdot$ Rory McRory $^{1}$. Chace Duma ${ }^{1} \cdot$ Sawyer Farmer ${ }^{1}$. Anthony Bravo ${ }^{1}$. \\ Christian Yassa ${ }^{1} \cdot$ Ami Sanathara $^{1} \cdot$ Elisa Singh $^{1} \cdot$ Benjamin Rapaport $^{1}$
}

Received: 11 May 2019 / Accepted: 15 July 2019 / Published online: 20 July 2019

(c) The Author(s) 2019

\begin{abstract}
We have chosen to test the safety of human intracerebroventricular (ICV) brain injections of autologous non-geneticallymodified adipose-derived stromal vascular fraction (ADSVF). In this IRB-approved trial, 24 patients received ICV ADSVF via an implanted reservoir between 5/22/14 and 5/22/17. Seven others were injected via their ventriculo-peritoneal shunts. Ten patients had Alzheimer's disease (AD), 6 had amyotrophic lateral sclerosis (ALS), 6 had progressive multiple sclerosis (MS-P), 6 had Parkinson's "Plus" (PD+), 1 had spinal cord injury, 1 had traumatic brain injury, and 1 had stroke. Median age was 74 (range 41-83). Injections were planned every 2-3 months. Thirty-one patients had 113 injections. Patients received SVF injection volumes of 3.5-20 cc (median: $4 \mathrm{cc}$ ) containing $4.05 \times 10^{5}$ to $6.2 \times 10^{7} \mathrm{cells} / \mathrm{cc}$, which contained an average of $8 \%$ hematopoietic and $7.5 \%$ adipose stem cells. Follow-up ranged from 0 to 36 months (median: 9.2 months). MRIs post injection(s) were unchanged, except for one AD patient whose hippocampal volume increased from $<5$ th percentile to 48 th percentile (NeuroQuant ${ }^{\circledR}$ volumetric MRI). Of the $10 \mathrm{AD}$ patients, 8 were stable or improved in tests of cognition. Two showed improvement in P-tau and $\beta$-amyloid levels. Of the 6 MS-P patients all are stable or improved. Four of 6 ALS patients died of disease progression. Twelve of 111 injections (11\%) led to 1-4 days of transient meningismus, and mild temperature elevation, which resolved with acetaminophen and/or dexamethasone. Two (1.8\% of injections) required hospitalization for these symptoms. One patient $(0.9 \%$ of injections) had his reservoir removed and later replaced for presumed infection. In this Phase 1 safety trial, ADSVF was safely injected into the human brain ventricular system in patients with no other treatment options. Secondary endpoints of clinical improvement or stability were particularly promising in the AD and MS-P groups. These results will be submitted for a Phase 2 FDA-approved trial.
\end{abstract}

Keywords Intracerebroventricular $\cdot$ Stem cells $\cdot$ Autologous stem cells $\cdot$ ADSC $\cdot$ Neurodegenerative disease $\cdot$ Alzheimer's disease $\cdot$ ALS $\cdot$ Multiple sclerosis $\cdot$ Stromal vascular fraction

\section{Introduction}

The ability to isolate human stem cells from numerous sources has grown over the past decade. These sources include fetal, adult, umbilical and embryonic. Mesenchymal stem cells are readily acquired from bone marrow and/

Christopher Duma

cduma@brainandspineoc.com

Extended author information available on the last page of the article or abdominal fat, and there is evidence that they may assist in repair of damaged tissue and actual regeneration of new cells. Unlike embryonic stem cells, which are known to be teratogenic, adult MSCs, especially adipose derived stem cells (ADSC), are simple to acquire, and lack the cultural controversy. There is also evidence that MSCs carry a degree of immunoprivilege [1-4].

ADSCs have proven to be a popular stem cell source with demonstrated therapeutic application in many areas of regenerative medicine. Terminology used for MSCs derived from 
fat varies in different publications and can be confusing. The cells in freshly isolated stromal vascular fraction (SVF) are a mixture of ADSCs, hematopoietic stem cells, endothelial cells, macrophages, T cells, pericytes, fibroblasts, mast cells, preadipocytes and others [5]. These cells can be cultured and after a few passages, a relatively homogeneous line of mesenchymal cells can be obtained, known as ADSCs [6].

ADSCs share similar characteristics with bone marrow MSCs [7-10], but research has shown that ADSCs carry significant advantages. They can be obtained in large quantities with significantly less invasive and safer methods from lipoaspirates $[3,11]$ and, more importantly for this report, they can differentiate toward neurogenic lineage $[5,12$, 13] propelling their use in a variety of animal trials to treat neurodegenerative conditions $[8,9,14]$. Transplantation of ADSCs has even been used in animal models of peripheral nerve damage, with evidence of their induction of trophic factors for a paracrine effect [15].

A growing number of clinical and experimental trials have shown the neuroprotective and neuroregenerative capabilities of employing ADSCs and/or their exosomes, for variable neurodegenerative disorders [16-32]. Very little has been written on the neuroprotective or neuroregenerative effects of SVF [33]. However, protective and regenerative effects on other organ tissues has [34-37]. This raises a very important practical question about the safest, most efficient, and simplest type of stem cell source. Can SVF alone, which is much quicker and simpler to obtain, without expansion, offer similar effects as ADSCs? Finally, neither SVF or ADSCs have been substantially studied as a direct injection into the human cerebroventricular system.

The potential routes of administration of these stem cell sources that have been tried can be divided into two major categories: systemic (intravenous/intra-arterial) and direct (intra-tissue) injections. Compared to intra-venous injections, the intra-arterial route of administration may be more direct but does not address yet another obstacle: the blood brain barrier (BBB). Haddad-Mashadrizeh, et al. [38] reported human ADSCs traversing the blood-brain barrier of the adult rat brain by 6 months post transplant. However, in the experiment, intra-parenchymal injection was used, which resulted in BBB damage at the site of injection, potentially skewing these results. Intranasal [39-42] and intrathecal [36, 43] routes have been used for intracerebral delivery of different stem cell types with variable outcomes. At the very least, with intrathecal administration, the cells layering by gravity to the bottom of the thecal sac, as well as the normal CSF circulatory route inhibiting cells from entering the deep brain parenchyma, are problematic.

The fact that a majority of the neurodegenerative disorders have multifactorial pathogenesis, require BBB penetration, and result in diffuse pathology of the brain, it is clear that a stem cell delivery method that combines safety, efficacy, and technical feasibility is necessary. Either the Ommaya reservoir, an implanted intraventricular catheter (historically used to obtain cerebrospinal fluid (CSF) or to deliver chemotherapy intrathecally), or a VP shunt, can serve as a perfect conduit for repeated stem cell injections into the human ventricular system [44].

In our pre-clinical animal trial we used autologous SVF obtained from processed human lipoaspirate (unpublished). The cells obtained with this approach were stereotactically injected into the lateral ventricle of 8 immunodefficient, Rowett Nude (RNU) rats. Histological and immunohistochemical investigation of the brains 3 weeks after injection did not detect any immune response and did not change normal cytoarchitectonics in the brains of the RNU rats. The SVF cells penetrated the ventricle wall and migrated into the brain parenchyma detected with anti-human mitochondria stain. Additional human stains may be required in future study to differentiate actual cell transfer versus exosome or other vesicular form of transfer. No obstruction to the spinal fluid circulation was found in the ventricles and no excessive growth of injected cells was detected (unpublished in-house data).

Here we report our 3-year results of a Phase I study in 31 patients who received intraventricular injections of autologous fresh ADSVF for treatment of various terminal or static neurodegenerative disorders recalcitrant to conventional therapeutic methods. To this end, we endeavored to determine the safety of single or multiple ICV injections of fresh SVF into the human brain for patients suffering with these illnesses with the hope that this route of injection would allow safe injection of autologous non-engineered progenitor stem cells, and serve as preliminary work to move into injection of purified, expanded cells. We felt this to be the safest, initial approach: using autologous, non-geneticallymodified, non-engineered, minimally-manipulated, nonexpanded cells. We acknowledge that precise dosing of these cells is impossible given innate patient variability, but look forward to addressing this in a future FDA-approved Phase 2 trial using SVF-derived expanded pure MSC stem cells.

This Phase 1 trial in 31 patients was designed to test safety of the procedure, but secondary endpoints of clinical improvement or stabilization and improvement in a number of objective parameters were also examined.

\section{Materials and methods}

\section{Patients}

Institutional Review Board (IRB)-directed (International Cell Surgical Society) animal studies were concluded and it was deemed safe by same IRB to proceed with a Phase I human safety trial. Patients with a variety of lethal 
neurodegenerative conditions who met criteria for selection (www.clinicaltrials.gov CSN111, an earlier trial using intravenous or intraarticular injections only) were included in this study. All patients had exhausted conventional therapies and Food and Drug Administration (FDA)-approved treatments for their conditions, had no other options for their lethal diseases, and were deteriorating clinically-most preparing for death. Patients met with a variety of consultants, to ascertain appropriateness for the procedure. Patients, their legal representatives, and/or nexst of kin were educated.

Conditions approved by the IRB and included in the study were ALS, Dementias (AD), Parkinson's Disease (PD) and Parkinson's "Plus" (PD+) (including multiple system atrophy (MSA) and progressive supranuclear palsy (PSP)), traumatic brain injury (TBI), multiple sclerosis-progressive form (MS-P), stroke, and spinal cord injury (SCI). Exclusion criteria included age less than 18 , pregnancy, severe coagulopathy, significant active infections, and metastatic or uncontrolled cancer. Anti-coagulation therapies were temporarily discontinued for the surgical procedures. Patients, or if deemed incompetent, a legally authorized representative (LAR)/next of kin, signed IRB-approved informed consents after a full transparent discussion of the potential risks and benefits of the procedures emphasizing the investigational nature of their SVF deployment. All patients underwent complete history and physical exams and appropriate imaging prior to their procedures. Baseline subjective and objective tests were administered.

The current study was conducted between $5 / 22 / 14$ and $5 / 22 / 17$. Twenty-four patients underwent SVF injection into the frontal horn of the lateral ventricle via an Ommaya reservoir. Seven others were injected via their existing VP shunts. Ten patients had AD, 6 had ALS, 6 had MS-P, 6 had PD+, 1 had TBI, 1 had SCI, and 1 had a stroke (Table 1). The median age was 74 (range: 41-83). Injections were planned every 2-3 months via the Ommaya reservoir or existing VP shunt. The SVF was procured using the FDA investigational device exemption (IDE)-pending liposuction and cell-separation technique described below. Thirty-one patients had at least one injection, 26 had at least 2, 14 had at least 4, and one patient had 15 injections, for a total of 113 injections.

Table 1 IRB-approved disease types for this study

\begin{tabular}{ll}
\hline Alzheimer's disease (AD) & 10 \\
Amyotrophic lateral sclerosis (ALS) & 6 \\
Multiple sclerosis-progressive form (MS-P) & 6 \\
Parkinson's-like syndromes (PD+, including PSP and MSA) & 6 \\
Traumatic brain injury (TBI) & 1 \\
Stroke & 1 \\
Spinal cord injury (SCI) & 1 \\
Total & 31 \\
\hline
\end{tabular}

Patients received intraventricular SVF injection volumes of 3.5-20 cc (median: $4 \mathrm{cc}$ ) containing $4.05 \times 10^{5}$ to $6.2 \times$ $10^{7}$ cells/cc and contained on average $8 \%$ hematopoietic and 7.5\% ADSCs by fluorescence-activated cell sorting (FACS) cytometry $[11,45]$.

\section{Ommaya reservoir implantation technique}

Preoperative computed tomography (CT) or magnetic resonance imaging (MRI) was performed on all patients. At a Certified Ambulatory Surgical Center (CASC), the patient was prepared and appropriate consents were signed. After a suitable plane of general endotracheal anesthesia was achieved and antibiotics were administered, the patient's head was placed on a donut cushion. General landmarks were identified. The Stealthstation ${ }^{\circledR}$ AxiEM $^{\text {TM }}$ system (Medtronic plc, Minnneapolis, MN, USA) received the downloaded MRI images, which were 3-dimensionally reconstructed by the surgeon. The electromagnetic reference was applied to the side of the patient's head and secured. The patient's scalp landmarks were traced obtaining an accuracy better than $2 \mathrm{~mm}$ for computer navigation. The area of the right frontal region was shaved, prepped and draped in the usual fashion. The planned incision, $3 \mathrm{~cm}$ lateral to midline and $2 \mathrm{~cm}$ anterior to the coronal suture, was infiltrated with 1:200,000 epinephrine solution of $1 \%$ lidocaine. The incision was made using a 10-blade scalpel. A burr hole was made at the frontal incision using an acorn drill bit. The dura was coagulated with a bipolar cautery and opened using an 11-blade scalpel. The leaves of dura were coagulated to the edges of the burr hole and bleeding was managed with bipolar electrocautery. The ventricular catheter was passed to a 4-6 cm depth using the computer guidance system. Cerebrospinal fluid (CSF) flow from the catheter was confirmed. The catheter was then cut to the correct length and connected to the Ommaya reservoir. It was tied using a $2-0$ silk tie and passed subgalealy behind the burr hole (Fig. 1). The cranial incision was closed using 2-0 Vicryl ${ }^{\circledR}$ (polyglactin 910) sutures on the galea and staples on the skin (Fig 1a)

Patients with an existing functioning VP shunt were exempt from the above procedure.

\section{Liposuction and SVF preparation technique}

One to 21 days (median: 4 days) passed between placement of the reservoir and SVF deployment. On day of deployment, in a Cell Surgical Network ${ }^{\circledR}$ (CSN, Rancho Mirage, California, USA)-affiliated certified ambulatory surgical center (CASC), patients underwent a proprietary liposuction technique followed by a cell centrifugation and incubation technique as previously described by our co-authors [11] (Fig. 1b). 

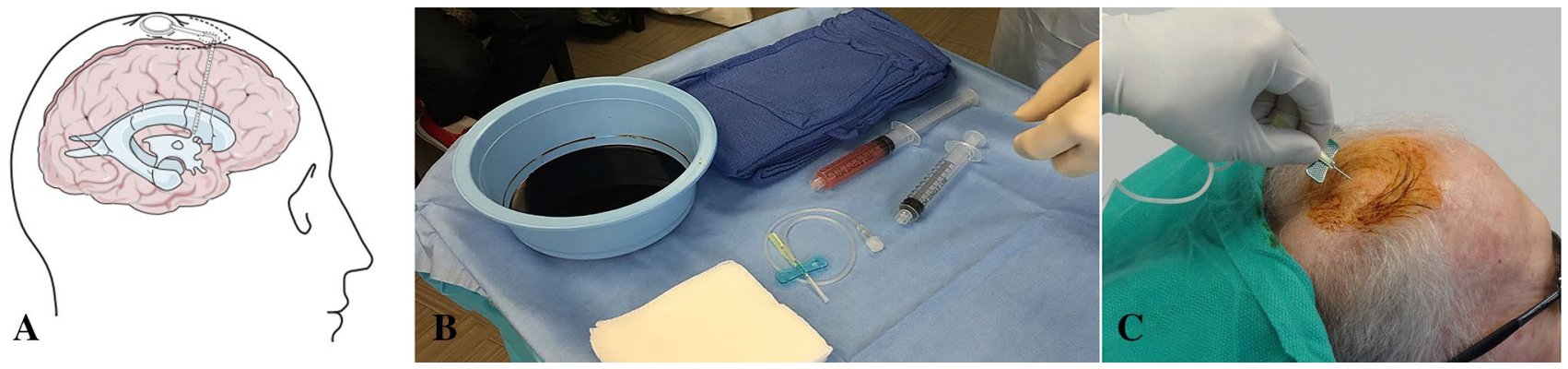

Fig. 1 a Artist's depiction of subgaleal placement of Ommaya reservoir with right-angle connection to right frontal intraventricular catheter. b Setup prior to injection (SVF is pink-colored solution in $10 \mathrm{cc}$

In our prior safety study [11], 25 different patient SVF samples were sent for flow cytometry to a reference laboratory at the University of California, San Diego (San Diego, California, USA). Photomicrography was used to document aggregation, basic cell count, and cell viability (Countess ${ }^{\mathrm{TM}}$ Invitrogen ${ }^{\mathrm{TM}}$; Thermo Fisher Scientific, Inc.; Waltham, Massachusetts, USA). Cell viability ranged from 65 to $95 \%$. Average SVF ADSC percentages were 8\% (based on high CD34+, and relatively low CD45-. Average SVF hematopoietic stem cell percentages were 7\% (based on low CD34 and relatively high CD45+ (Fig. 2). Exact determination of the specificity of CD34 for ADCs versus hematopoietic SCs has previously been scrutinized [46-48], and is subject for further investigation.

No patient data from that work were in our current series. We only extrapolated the approximate number of cells administered to each patient in the current study from this previous work. The current study was a phase 1 safety trial, and we wanted to administer as many cells as possible within a safe volume of CSF. Therefore, exact counts were not tantamount in the current study. Going forward, a different study, with purified, expanded ADSCs will become more accurate vis-à-vis exact cell counts. Even with that, however, cell viability will vary between the time of cell acquisition and the time of ICV deployment. We understand that SVF samples vary per number of ADSCs, per patient per volume. For this reason the current study made no effort to "standardize" an exact number of cells per injection.

There was essentially no interval of time between cell preparation and deployment. After the last centrifugation, and acquisition of the fresh SVF aliquot, the cells were deployed intracerebroventricularly within minutes. The total time from liposuction to ICV deployment was approximately $2.5 \mathrm{~h}$ for all patients.

\section{SVF injection technique}

The area of the subgaleal Ommaya reservoir, or the reservoir portion of an existing VP shunt, was prepped and syringe). c Injection technique, using a $23-\mathrm{G}$ butterfly needle, via reservoir puncture
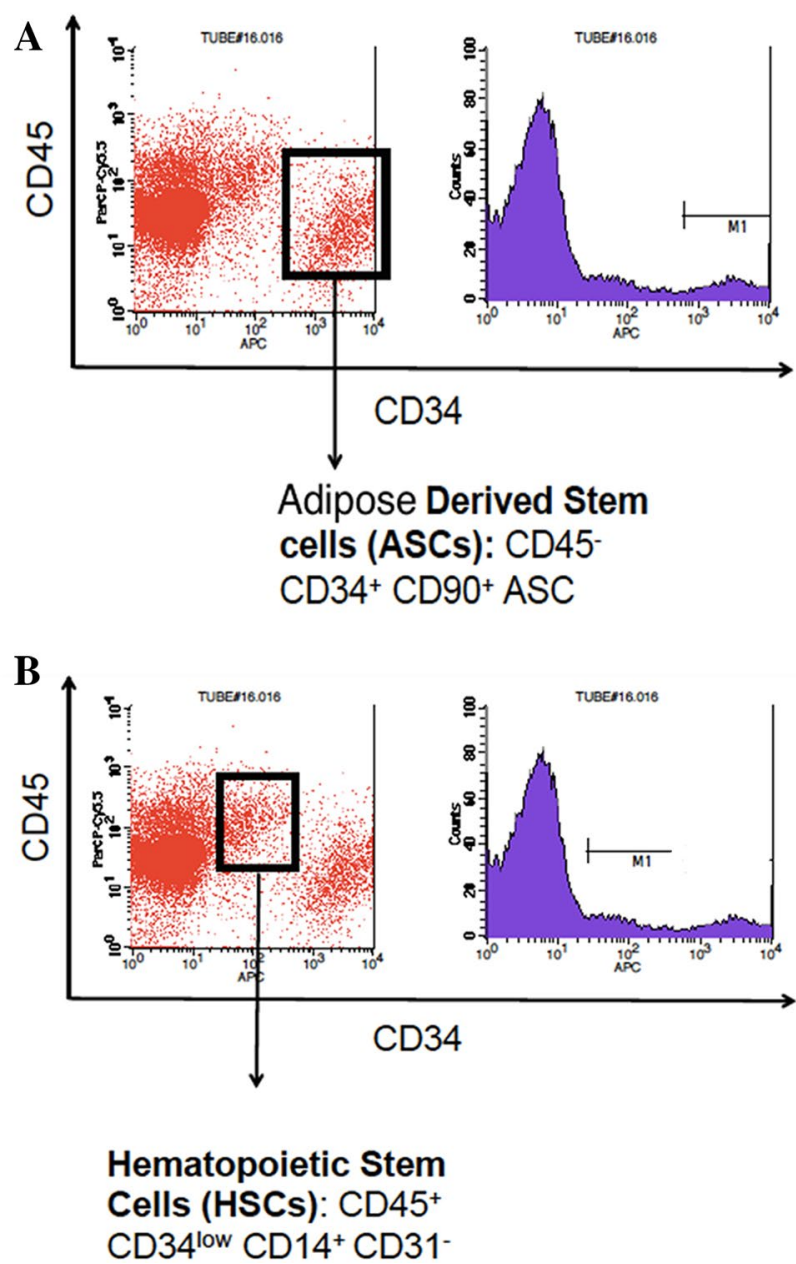

Fig. 2 Flow cytometry of SVF samples distinguishing ADSCs from hematopoietic stem cells

draped. A 21-gauge butterfly needle attached to a 10 -cc syringe was inserted, CSF withdrawn to a volume $2 \mathrm{cc}$ greater than the SVF sample. The syringe was exchanged for the SVF syringe and the SVF was fully injected into the Ommaya reservoir (Fig. 1c). This was then flushed 
with $2 \mathrm{cc}$ of the reserved CSF, such that total volume of CSF removed equaled the total volume of SVF suspension injected (a volume neutral exchange). The needle was removed and a sterile bandage was placed over the injection site (Fig. 1c).

In patients with existing VP shunts, the valve was programmed to the slowest flow setting. During injection, the distal peritoneal catheter was manually occluded using digital pressure on the peritoneal side of the valve to avoid spillage of SVF via the abdominal catheter. The valve was left in this slow drainage position for 1-3 days. Then, the patient returned to clinic to have the valve reset to their preinjection setting.

\section{Follow-up and secondary endpoint testing}

The online Health Insurance Portability and Accountability Act of 1996 (or HIPAA) database was used to track patients for safety and outcome data. In most cases, patients reported any adverse outcomes directly to the treating physician or to the database. Severe adverse events were reported to the IRB. Th offices of California Stem Cell Treatment Center oversaw this data. Secondary endpoints were evaluated although not the primary focus of this Phase 1 trial.

\section{Secondary endpoint test for multiple sclerosis}

\section{Kurtzke expanded disability status Scale (EDSS)}

The Functional System Score (FSS) and EDSS are two of the most widely used clinical assessment scales for MS [49]. Seven functional systems are rated. These ratings plus gait analysis are used to score the EDSS. The EDSS is a rating scale ranging from 0 (normal neurologic examination) to 10 (death due to MS) in half-point increments. It has been used in virtually every major clinical trial that has been conducted in MS.

\section{Secondary endpoint tests for Alzheimer's disease and dementia}

Mild cognitive impairment $(\mathrm{MCl})$ screen $^{\mathrm{TM}}[50]$

The high accuracy of MCI Screen ${ }^{\mathrm{TM}}$ is achieved by applying scoring methods to the protocols of the Consortium to Establish a Registry for Alzheimer's Disease (CERAD) 10-word recall test and the Alzheimer's Disease Assessment ScaleCognitive subscale (ADAS-Cog) 10-word recall test. The MCI Screen ${ }^{\mathrm{TM}}$ uses recall trials compared to the normal range for the patient's peer group.
Memory Performance Index [50] (MPI), repeatable battery for the assessment of neuropsychological status [51] (RBANS), and mini mental state examination (MMSE)

The Memory Performance Index (MPI) quantifies a patient's pattern of recall on a scale ranged from 0 to 100 and classifies the score based the patient's peer group. The RBANS is a brief, test measuring attention, language, visuospatial/ constructional abilities, and immediate and delayed memory. The MMSE is not specific for AD but is one of the mostused tests of cognitive function [52].

\section{NeuroQuant ${ }^{\oplus}$ volumetric magnetic resonance imaging}

MRI brain images were processed by the NeuroQuant ${ }^{\circledR}$ software package (CorTechs Labs, Inc.; La Jolla, California, USA), a tool is used to measure volumes of brain structures in MRI images compared to aged-matched normals. The software calculates volumes of hippocampal images with graphic color overlays, the volume of which is constructed with artificial intelligence.

\section{ADmark ${ }^{\circledast}$ phospho-tau/total-tau/A beta 42 cerebrospinal fluid analysis and interpretation (symptomatic) (Athena Diagnostics ${ }^{\circledR}$, Marlborough, MA, USA)}

This CSF evaluation for AD looks at levels of phosphorylated tau protein (P-tau), total tau protein, and $\mathrm{A} ß 42$ peptide-which determine the likelihood that individuals with early onset dementia have AD. This assay detects ApoE2, E3, E4 alleles and levels of Phosphorylated-Tau protein, Total-Tau protein, and Ab42. The methodology is ELISA, Restriction Fragment Length Polymorphism (RFLP). The reference range is correlation of levels of markers of Phosphorylated-Tau, Total-Tau, and Ab42, Presence of ApoE2, E3, E4 alleles [53].

\section{Secondary endpoint tests for $\mathrm{SCl}$, stroke, TBI, ALS, and MSA/PD+}

Clinical improvement only, based on neurological examination.

\section{Results}

\section{Safety}

Follow-up ranged from 2 to 36 months (median: 9.2 months, mean: 13.2 months). Twenty-four Ommaya reservoir and 7 VP shunt implantations led to no infections or complications other than mild headache, or pain at the surgical sites, for less than $24 \mathrm{~h}$. 
Twelve of 113 injections (11\%) led to 1-2 days of transient meningismus, headache, and mild temperature elevation (up to $2^{\circ}$ Fahrenheit) managed solely with ibuprofen or acetaminophen. One patient $(0.8 \%)$ required removal of the reservoir for presumed infection (streptococcus sanguinis, thought later to have been an oral contaminant which seeded the reservoir via bacteremia), was treated with antibiotics, and later electively had the reservoir replaced.

Four other patients (3.6\% of total injections) required hospitalization within 30 days after one of their injections. Only 2 of which (1.8\% of total injections) were felt to be possibly related to the SVF injection. One patient had a high fever accompanied by diarrhea and vomiting 2 days after injection and was admitted to the hospital. CSF cultures from the Ommaya reservoir showed no growth. The patient was sent home on a short course of antibiotics for pneumonia and prophylactically for his meningismus; the reservoir did not require removal. A second patient required conversion of his reservoir to a VP shunt for progressive symptoms of hydrocephalus felt unrelated to SVF injection, but rather failure of his existing lumboperitoneal shunt previously placed for symptoms of normal pressure hydrocephalus. A third patient with a long history of myocardial infarctions (MIs) presented with an ST elevation MI and was admitted for a fifth cardiac stenting procedure. The fourth patient, diagnosed with ALS, had a local infection of his gastrostomy feeding tube which necessitated elective prophylactic removal of the Ommaya reservoir and treatment of his local infection. No patient experienced seizure activity.

MRIs performed a median of 1 year post injection(s) in 16 of 31 patients were unchanged.

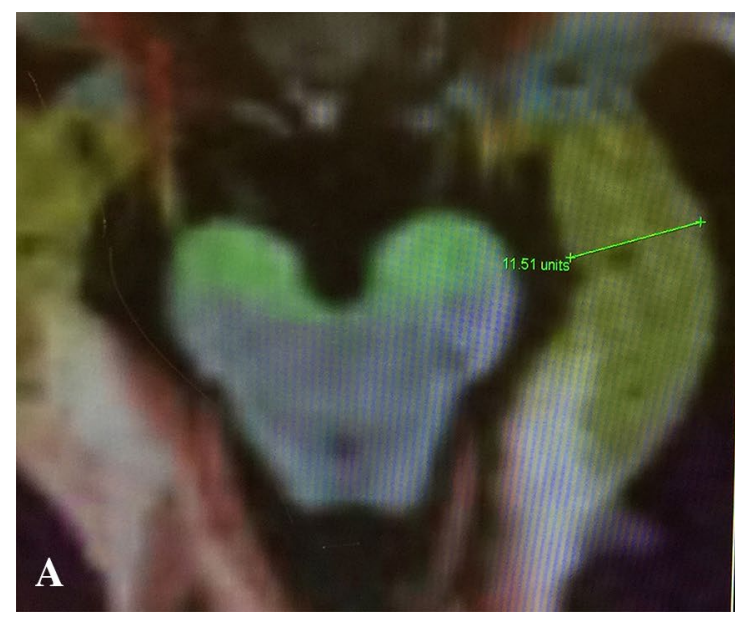

Fig. 3 Hippocampal volume on NeuroQuant ${ }^{\circledR}$ MRI analysis in the 3 patients who had this done with at least 4 months follow-up. Note patient \#10 whose hippocampal volume increased from $<5$ th percen-

\section{Secondary endpoints}

Disease stability or improvement was seen in $87.5 \%$ of the combined AD and MS-P population. Of the 6 ALS patients, 4 are deceased and 2 are stable; of the 6 MS-P patients, all are stable or have improved. Of the $6 \mathrm{MSA} / \mathrm{PD}+$ patients, 3 are deceased and 2 are stable and one withdrew as they were getting worse (after one dose). All deaths were felt related to natural disease progression. The TBI patient is subjectively improved and the stroke patient is stable.

Four AD patients underwent pre-SVF and inter-SVF NeuroQuant ${ }^{\circledR}$ volumetric analyses. In one AD patient, the hippocampal volume increased from $<5$ th percentile to 48th percentile after 2 years of follow-up and 8 SVF injections (Fig. 3). Of the $10 \mathrm{AD}$ patients, 8 are stable or have improved in tests of cognition (Fig. 4) and 3 showed a reduction in P-tau and improvement in the Amyloid- $\beta$ to Total Tau ratio (ATI) in CSF testing (Athena Diagnostics ${ }^{\circledR}$ ) over 8 months, with a trend toward normalization (Fig. 5). One of 6 MS-P patients' EDSS scores improved from 7.5 to 6.5 (from wheelchair bound to ambulating 20 yards with a walker) after $12 \mathrm{SVF}$ injections over 2 years. Another showed improvement in that score as well. The remainder have remained stable with an average of only 2 SVF injections over the same period (Table 2).

\section{Discussion}

SVF has documented anti-inflammatory and immune-modulatory effects [11]. There is a growing bulk of data that ADSCs may be used successfully for the treatment of human neurodegenerative disorders $[54,55]$. Autologous SVF contains not only both hematopoietic and fat-derived stem cells,

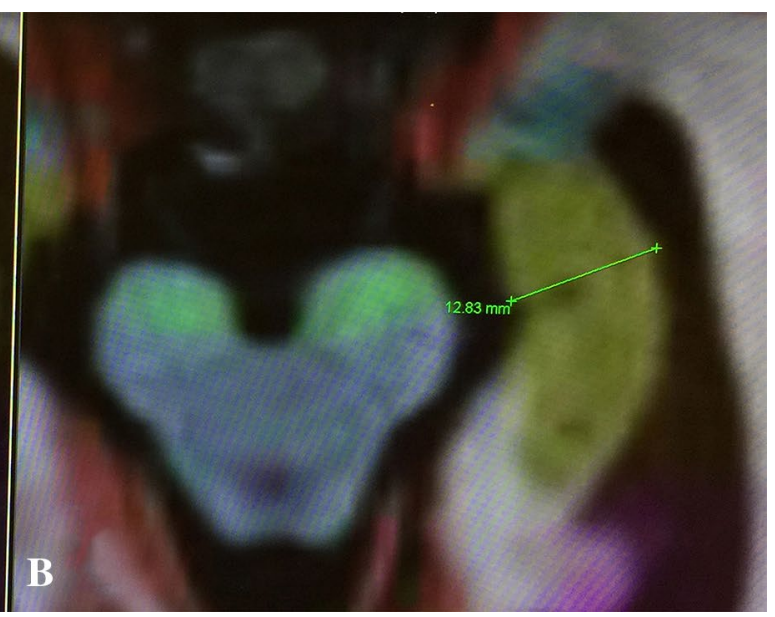

tile for age prior to ICV SVF administration, to 49th percentile (normal for age) 2 years later, after 8 injections 
Fig. 4 MPI scores for 4 patients followed at least 4 months compared to a "typical" AD patient, versus time, showing typical unrelenting decline in score in the "typical" AD patient, but stabilization or improvement after SVF injection in the 4 patients tested

\section{Memory Performance Index}

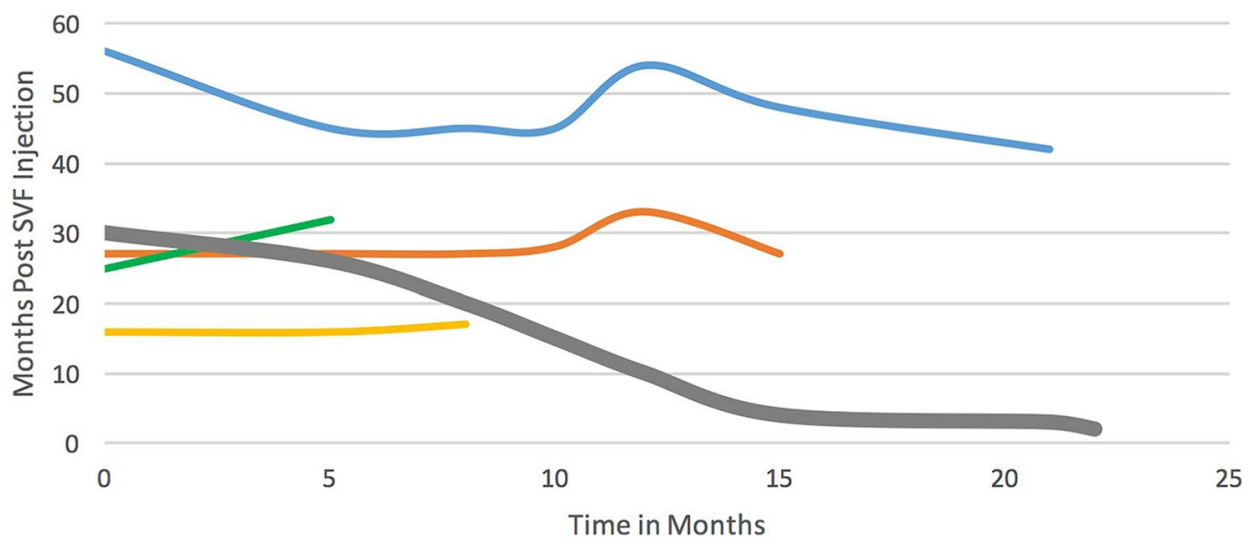

TYPICAL PROGRESSION

\section{P-Tau levels for 3 consecutive AD patients - Downtrend best} With trendlines

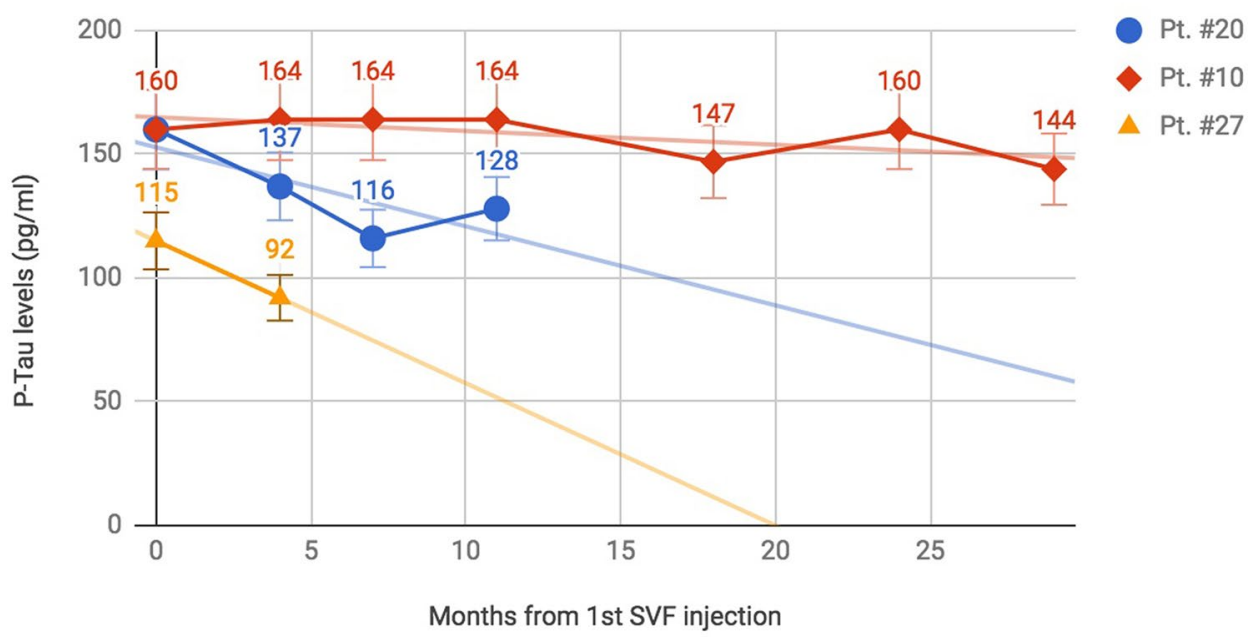

\section{ATI calculation for 3 consecutive AD patients - Uptrend best} With trendlines

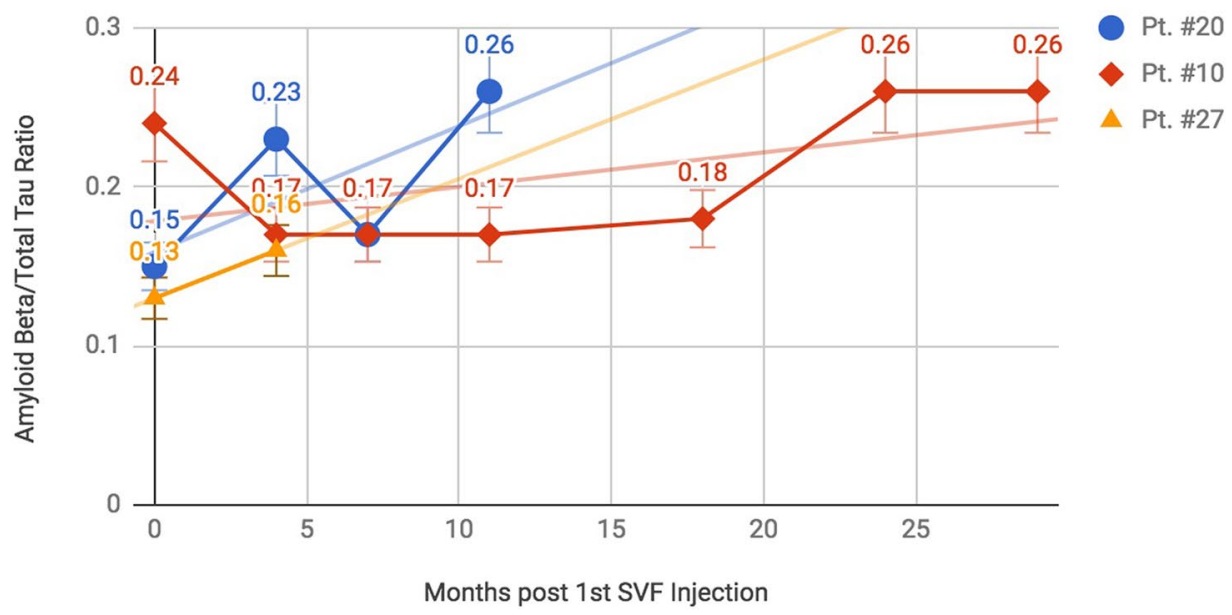


Table 2 Demographics, follow-up and outcome for 31 patients

\begin{tabular}{|c|c|c|c|c|c|c|c|}
\hline Dx & Pt ID & Age at start/sex & $\begin{array}{l}\text { Duration of illness } \\
\text { prior to 1st injection } \\
\text { (years) }\end{array}$ & $\begin{array}{l}\text { No. of } \\
\text { injec- } \\
\text { tions }\end{array}$ & $\begin{array}{l}\text { FU } \\
\text { interval } \\
\text { (months) }\end{array}$ & Status & Complication \\
\hline \multirow[t]{10}{*}{$\mathrm{AD}$} & 10 & $82 / \mathrm{M}$ & 5 & 8 & 36 & $\begin{array}{l}\text { Better p-tau decrease } \\
\text { from } 160 \text { to } 140 \mathrm{pg} / \mathrm{ml} \\
\text { hippocampal volume } \\
\text { increased from }<5 \text { th } \\
\text { percentile to } 49 \text { th pere- } \\
\text { centile, (volume); MPI } \\
\text { improved at } 13 \text { month }\end{array}$ & None \\
\hline & 13 & $74 / \mathrm{F}$ & 5 & 4 & 20.7 & Subjectively better & None \\
\hline & 18 & $66 / \mathrm{M}$ & 5 & 4 & 15.6 & Subjectively better & None \\
\hline & 20 & $78 / \mathrm{M}$ & 4 & 7 & 13 & $\begin{array}{l}\text { Better p-tau decrease } \\
\text { from } 160 \text { to } 128 \mathrm{pg} / \mathrm{ml} \\
\text { hippocampal volume } \\
\text { increased from } 21 \mathrm{st} \text { to } \\
\text { 22nd percentile MPI } \\
\text { improved at } 12 \text { month }\end{array}$ & $\begin{array}{l}\text { After } 7 \text { th injection, acute } \\
\text { hydrocephalus, required } \\
\text { conversion of ommaya to } \\
\text { vp shunt }\end{array}$ \\
\hline & 24 & $82 / \mathrm{M}$ & 4 & 3 & 7.3 & Unchanged & None \\
\hline & 25 & $71 / \mathrm{F}$ & 4.5 & 1 & 5.7 & Unchanged & None \\
\hline & 27 & $79 / \mathrm{F}$ & 20 & 2 & 3.8 & $\begin{array}{l}\text { Better p-tau decreased } \\
\text { from } 115 \text { to } 92 \mathrm{pg} / \\
\text { ml MPI improved at } \\
10 \text { months }\end{array}$ & None \\
\hline & 29 & $74 / \mathrm{M}$ & 5 & 2 & 3.7 & Unchanged & None \\
\hline & 30 & $77 / \mathrm{F}$ & 3.5 & 1 & 0.5 & Unchanged & \\
\hline & 31 & $72 / \mathrm{M}$ & 5 & 1 & 0.4 & Unchanged & $\begin{array}{l}\text { Hospitalized for severe } \\
\text { meningismus after 1st } \\
\text { injection. No infection. } \\
\text { Returned to full capacity }\end{array}$ \\
\hline \multirow[t]{6}{*}{ ALS } & $1 / \mathrm{F}$ & $59 / \mathrm{F}$ & 2 & 4 & 9.2 & Deceased & None \\
\hline & 2 & $71 / \mathrm{M}$ & 7 & 2 & 3.9 & Deceased & $\begin{array}{l}\text { Prophylactic removal of } \\
\text { Ommaya reservoir for } \\
\text { gastrostomy feeding tube } \\
\text { infection }\end{array}$ \\
\hline & 12 & $45 / \mathrm{M}$ & 1 & 3 & 27.8 & Stable & None \\
\hline & 14 & 64/M & 1 & 5 & 5.7 & Deceased & None \\
\hline & 19 & $72 / \mathrm{M}$ & 1 & 4 & 3.8 & Deceased & None \\
\hline & 22 & $41 / \mathrm{M}$ & 5 & 4 & 12.3 & Stable & None \\
\hline \multirow[t]{6}{*}{ MS-P } & 7 & $56 / \mathrm{F}$ & 2 & 4 & 27.9 & Better: EDSS 7.5 to 6.5 & None \\
\hline & 11 & $58 / \mathrm{F}$ & 30 & 2 & 25 & $\begin{array}{l}\text { Worse (stopped treatment } \\
\text { electively) }\end{array}$ & None \\
\hline & 16 & $56 / \mathrm{F}$ & 12 & 3 & 19.1 & Stable & None \\
\hline & 3 & $42 / \mathrm{F}$ & 8 & 15 & 32 & $\begin{array}{l}\text { Better: EDSS improved } \\
\text { from } 6.0 \text { to } 5.5\end{array}$ & None \\
\hline & 26 & $62 / \mathrm{F}$ & 9 & 2 & 5.3 & EDSS stable & None \\
\hline & 5 & $70 / \mathrm{F}$ & 4 & 4 & 27.2 & Lost to fu & None \\
\hline \multirow[t]{3}{*}{ Park +/MSA } & 8 & $72 / \mathrm{F}$ & 1.5 & 4 & 7.7 & Deceased & None \\
\hline & 4 & $67 / \mathrm{M}$ & 13 & 1 & 31.1 & $\begin{array}{l}\text { Worse (stopped treatment } \\
\text { electively) }\end{array}$ & None \\
\hline & 23 & $77 / \mathrm{M}$ & 9 & 6 & 10.8 & Stable & None \\
\hline Park + PSP & 6 & $81 / \mathrm{M}$ & 2 & 3 & 4 & Deceased & None \\
\hline
\end{tabular}


Table 2 (continued)

\begin{tabular}{|c|c|c|c|c|c|c|c|}
\hline Dx & Pt ID & Age at start/sex & $\begin{array}{l}\text { Duration of illness } \\
\text { prior to 1st injection } \\
\text { (years) }\end{array}$ & $\begin{array}{l}\text { No. of } \\
\text { injec- } \\
\text { tions }\end{array}$ & $\begin{array}{l}\text { FU } \\
\text { interval } \\
\text { (months) }\end{array}$ & Status & Complication \\
\hline & 21 & $55 / \mathrm{M}$ & 2 & 2 & 1.9 & Deceased & $\begin{array}{l}\text { Hospitalized after } 2 \text { nd } \\
\text { injection for meningis- } \\
\text { mus, oral flora grew from } \\
\text { csf culture, Ommaya } \\
\text { removed, replaced } \\
2 \text { weeks later }\end{array}$ \\
\hline & 28 & $73 / \mathrm{F}$ & 3.5 & 2 & 2.1 & Better clinical exam & None \\
\hline SCI & 17 & $44 / \mathrm{F}$ & 5 & 6 & 19 & Better clinical exam & None \\
\hline Stroke & 15 & $70 / \mathrm{F}$ & 1 & 1 & 0 & Stable & None \\
\hline TBI & 9 & $67 / \mathrm{M}$ & 2 & 3 & 26.3 & $\begin{array}{c}\text { Worse (since stopping } \\
\text { treatment electively) }\end{array}$ & None \\
\hline
\end{tabular}

but also has indigenous anti-inflammatory properties [56]. It therefore, made sense to move forward using SVF in a number of neurodegenerative disorders where an inflammatory component might be implicated. AD [57, 58] and MS [59] are two such devastating diseases. ALS and PD+ syndromes may also be autoimmune and inflammatory in nature, as may TBI or chronic traumatic encephalopathy (CTE) [21, $60,61]$. Of course, the second capability of stem cells, to actually regenerate dead or diseased neurons, also needed experimentation.

As ADCS are entering the practical arena of translational medicine, the issue of refining practical aspects of the most safe and effective delivery methods has become of utmost importance. There should be two major types of the delivery routes considered: intraparenchymal and systemic. Intraparenchymal or intracerebral injection presents a significant degree of two major common neurosurgical risks-bleeding and infection. Furthermore, even though there are multiple reports of high level of migratory capability of stem cells in animal experiments $[62,63]$, it is difficult to expect the stem cells to repopulate the entire human brain and/or spinal cord, which is crucial for efficacy of the treatment of the disorders with widely spread neuronal degeneration. Another disadvantage of the intraparenchymal injection is unavoidable, albeit transient, disruption of the blood-brain barrier (BBB). Alas, another limitation for using direct intraparenchymal injection is that such an approach does not allow for the injection of large numbers of stem cells due to comparatively high density of the brain tissue.

Intravenous and intra-arterial administration routes have yielded varied outcomes. This may be due to equally varied biodistribution. In preclinical and first clinical experiments, intravenous injection has been the most popular approach $[64,65]$ for the treatment of orthopedic, cardiovascular, erectile, and other disorders. The intravenous delivery is safe [11], but may be optimized by regional deployment. Intra-arterial delivery was also investigated. It provides a better biodistribution of the stem cells through the brain, but increases the risk of cerebral lesions/microstrokes [66].

Overall, this analysis demonstrates four key requirements to an ideal delivery tool: (a) safety; (b) circumventing BBB presumably via glymphatic system distribution; (c) ensuring biodistribution throughout the entire brain, and (d) technical feasibility. Deployment of SVF via an ICV Ommaya reservoir or VP shunt satisfies these requirements most fully. They allow for multiple injections safely, which presented an additional important feature for our clinical trial. Similarly, a pre-existing, or electively implanted VP shunt may also serve as a conduit for stem cell delivery.

To date, there are only a few publications reporting use of an implanted Ommaya reservoir into the brain for injection of stem cells from an autologous mesenchymal source. Fauzi et al., injected autologous MSCs from bone marrow into the cerebroventricular system of 2 patients for chronic vegetative state secondary to devastating intracerebral hemorrhage. One-year follow-up and multiple injections not only showed safety, but neurologic improvement in the 2 patients [67]. Three anecdotal case reports using stem cells derived from fetal, umbilical and bone marrow sources, injected into the brain have also been reported; 2 for fetal hypoxia [68, 69] and 1 for ALS [70]. There are no reports of using a VP shunt for this use.

\section{Mechanisms of action}

Possible mechanisms of action include the following: antiinflammatory effect, angiogenesis, improvement in neuronal pruning, neurogenesis, inhibition of angiogenesis, expression of trophic factors, telomere preservation, and inhibition of cell death. An interesting observation in the current study was that most patients with MS-P and AD noticed an improvement in their clinical function within the first week of injection followed by a "wearing-off" effect after 6-8 weeks. Our patients, whom have had more than 
6 injections, have had an anecdotal decrease in the "wearing-off" effect to the extent that future injections could be delayed up to 4 months. This suggests a permanence to an anti-inflammatory effect, a rebuilding of neurons and their function, and/or an epigenetic phenomenon of genetic remodeling.

\section{Rejection and tumorogenicity}

We found no evidence of rejection of the injected SVF in this study. Nor have we found such evidence in our experience with intraarticular or IV administration in more than 8000 patients [11]. As these cells are autologous, rejection is not expected, however longer term follow-up is necessary to determine tumorogenicity. Ra et al., have reported no evidence of tumor formation in their experience administering autologous SVF [71].

\section{ALS}

In a superoxide dismutase 1 G93A-mutated (SOD1G93A) ALS mouse model, ICV delivery of ADSCs delays the onset of ALS and extends survival [29]. After transplantation, elevated levels of neurotrophic factors were found in the spinal cord of this ALS mouse model. In another report, upregulation of glial-derived neurotrophic factor occurred, indicating a role in neuroprotection as well [72]. Indeed many experimental reports for using ADSCs for this disease exist [29, 61, 73-83]. Of note, Habisch, et al. [83]., reported the inefficacy in obtaining adequate stem cell levels in the brain parenchyma with intrathecal injection due to layering out secondary to the effect of gravity. This is one of the largest series of intrathecal injection of stem cells in the human, which led us alternatively to direct ICV deployment.

Results in our late-stage patients were unimpressive, perhaps ADSCs injected in earlier phases of the disease could have more effect.

\section{AD}

Intracerebral administration of ADSCs in amyloid precursor protein/presenilin 1 (APP/PS1) double transgenic mice improves the recovery of spatial learning/memory ability [84]. Intravenous administration of ADSCs has also been shown to have beneficial effects dementia in AD mouse models [85]. Overall, there is growing preclinical evidence that transplantation of ADSCs and/or their exosomes, may potentially prevent the neurodegeneration associated with AD [86-88]. The autoimmune component of this disease remains to be elucidated [89-91]. The use of ADSCs, exosomes, and SVF have all shown promising results in experimental models [20, 84, 85, 87, 92-98]. Our results in humans, especially with reduction in P-tau levels and actual growth of hippocampal tissue, are exceedingly promising. In addition, our improvement/stabilization in MMSE scores underlies a clinical efficacy of SVF in the human as well.

\section{MS}

MS-P is the progressive form of this well-known inflammatory disease affecting myelinated axons. Once diagnosed, this disease leads to degeneration of the myelin sheath surrounding neural axons, leading to loss of motor and sensory function subsequently leading to death. There is evidence supporting a role the antiinflammatory capacity of ADSCs for this devastating disorder [99-101], as well as their neuron-rebuilding capability. Indeed, both SVF and ADSCs appear to be effective in animal models of this disease [99, 102-111]. Bowles, et al., reported an advantage of SVF over ADSCs in the experimental autoimmune encephalomyelitis (EAE) model in the mouse [103, 104].

\section{Complications and serious adverse events (SAE)}

Of the patients with apparent aseptic meningitis, it is known that patients with intraventricular hemorrhage experience BBB breakdown and expression of various cytokineswhich have induced the breakdown. Theoretically, injection of SVF is not dissimilar to an intraventricular hemorrhage in that the cells creating the inflammation are similar in both respects. We fully expected signs of meningismus in our patient population and indeed observed these signs in $11 \%$ of patients. All recovered perfectly within $2-5$ days post symptoms. In theory, such a disruption of the BBB would be clinically advantageous for the patient in that this is a natural (albeit uncomfortable) method of breaking open the BBB; thus, allowing the stem cells to better and more thoroughly infiltrate the parenchyma [112-116]. It is possible that this complication correlates with volume of SVF injected, density of the non-nucleated cells in the SVF specimen, inclusion of pro-inflammatory endogenous red blood cells in the SVF product, etc. This will remain to be elucidated in the future with larger sample sizes. "Lipoid meningitis" has been reported as a consequence of heterologous implantation of abdominal fat into the cerebrum for neurosurgical procedures [117, 118]. In this series of patients, our experience with transient meningeal irritation is similar to these reports.

One patient required conversion of his lumboperitoneal shunt to a VP shunt for signs of hydrocephalus. It is entirely possible that injection of these cells can lead to this complication either due to ependymal irritation, irritation of arachnoid villi, or mechanical obstruction of the aqueduct of Sylvius. For this reason, the authors are recommending VP shunting rather than Ommaya reservoir placements for all future patients. 


\section{Secondary endpoints}

Secondary endpoints showed very promising results in the $\mathrm{AD}$ and MS-P groups. In particular, the AD patient, who received 12 injections over 3 years, showed signs of hippocampal volume increase on NeuroQuant ${ }^{\circledR}$ volumetric MRI to the median volume for age-matched patients without $\mathrm{AD}$ and a stabilization of his MPI and MCI Screen ${ }^{\mathrm{TM}}$. This phenomenon has never been reported after pharmaceutical use. Another AD patient, who received 4 injections, showed P-tau and ATI trending toward normalization over 8 months. The MS-P patient who received 15 injections over 3 years went from being wheelchair bound to ambulating with a walker and driving a car without any change in medical therapy. There was an anecdotal correlation between improvement and number of injections. There was also an anecdotal decline in patients 4-6 weeks after injection, prompting patients to return for a "booster" injection and supporting the need for multiple injections over time.

Of our 31 patients, 6 died. The typical patient with MSA/ PD+ and ALS usually survives no longer than 3-6 years after diagnosis. Of our 12 patients with these diagnoses, the 6 deaths were in these two subgroups; their deaths were due to respiratory complications of their diseases. During our 3 -year follow-up we would expect this number of deaths in these subgroups of patients. Earlier intervention in these subgroups may yield better results.

\section{Conclusion}

We report the safety of single and repeat ICV injection of autologous fresh SVF containing progenitor stem cells in 113 injections in 31 patients followed for 3 years. ADSVF was safely injected into the human brain ventricular system over multiple injections via an implanted conduit. The secondary endpoints of clinical improvement or stability were promising in the $\mathrm{AD}$ and MS-P groups in particular. Complications can be minimized with prophylactic dexamethasone and the use of a VP shunt in lieu of an Ommaya reservoir. The mortality in patients with ALS and MSA appeared unaffected by the cells, but this population may need earlier intervention.

The limitation of this study is the innate patient variability of the number of cells and the quality of cells injected. A Phase 2, FDA-approved study using this injection technique with SVF-derived autologous pure MSC stem cell lines can address this variability. Purified autologous cells can be accurately dosed and qualitatively verified pre-injection. We plan submission of this Phase 1 work to the FDA to progress to a Phase 2 trial in the AD and MS-P populations and in early-diagnostic subsets of ALS and MSA.

\section{Compliance with ethical standards}

Conflict of interest I have no conflict of interest with the IRB, or the source of the disposable materials used to prepare the SVF. In particular I receive no compensation from the Cell Surgical Network, or ICSS, I received usual and customary compensation for the surgical procedures I performed in patients for this study.

Ethical approval This study was approved by the ICSS IRB. IRB00009188. IORG number: IORG0007657.

Open Access This article is distributed under the terms of the Creative Commons Attribution 4.0 International License (http://creativeco mmons.org/licenses/by/4.0/), which permits unrestricted use, distribution, and reproduction in any medium, provided you give appropriate credit to the original author(s) and the source, provide a link to the Creative Commons license, and indicate if changes were made.

\section{References}

1. Lo Furno D, Mannino G, Cardile V, Parenti R, Giuffrida R (2016) Potential therapeutic applications of adipose-derived mesenchymal stem cells. Stem Cells Dev. https://doi.org/10.1089/ scd.2016.0135

2. Ogura F, Wakao S, Kuroda Y, Tsuchiyama K, Bagheri M, Heneidi S, Chazenbalk G, Aiba S, Dezawa M (2014) Human adipose tissue possesses a unique population of pluripotent stem cells with nontumorigenic and low telomerase activities: potential implications in regenerative medicine. Stem Cells Dev 23(7):717-728. https://doi.org/10.1089/scd.2013.0473

3. Peng L, Jia Z, Yin X, Zhang X, Liu Y, Chen P, Ma K, Zhou C (2008) Comparative analysis of mesenchymal stem cells from bone marrow, cartilage, and adipose tissue. Stem Cells Dev 17(4):761-773. https://doi.org/10.1089/scd.2007.0217

4. Kim HW, Lee HS, Kang JM, Bae SH, Kim C, Lee SH, Schwarz J, Kim GJ, Kim JS, Cha DH, Kim J, Chang SW, Lee TH, Moon J (2018) Dual effects of human placenta-derived neural cells on neuroprotection and the inhibition of neuroinflammation in a Rodent model of Parkinson's disease. Cell Transpl 27(5):814830. https://doi.org/10.1177/0963689718766324

5. Gentile P, Orlandi A, Scioli MG, Di Pasquali C, Bocchini I, Cervelli V (2012) Concise review: adipose-derived stromal vascular fraction cells and platelet-rich plasma: basic and clinical implications for tissue engineering therapies in regenerative surgery. Stem Cells Transl Med 1(3):230-236. https://doi.org/10.5966/ sctm.2011-0054

6. Zuk PA, Zhu M, Mizuno H, Huang J, Futrell JW, Katz AJ, Benhaim P, Lorenz HP, Hedrick MH (2001) Multilineage cells from human adipose tissue: implications for cell-based therapies. Tissue Eng 7(2):211-228. https://doi.org/10.1089/1076327013 00062859

7. Hsiao ST, Asgari A, Lokmic Z, Sinclair R, Dusting GJ, Lim SY, Dilley RJ (2012) Comparative analysis of paracrine factor expression in human adult mesenchymal stem cells derived from bone marrow, adipose, and dermal tissue. Stem Cells Dev 21(12):2189-2203. https://doi.org/10.1089/scd.2011.0674

8. Mosna F, Sensebe L, Krampera M (2010) Human bone marrow and adipose tissue mesenchymal stem cells: a user's guide. Stem Cells Dev 19(10):1449-1470. https://doi.org/10.1089/ scd. 2010.0140 
9. Strioga M, Viswanathan S, Darinskas A, Slaby O, Michalek J (2012) Same or not the same? Comparison of adipose tissuederived versus bone marrow-derived mesenchymal stem and stromal cells. Stem Cells Dev 21(14):2724-2752. https://doi. org/10.1089/scd.2011.0722

10. Chang YH, Liu HW, Wu KC, Ding DC (2016) Mesenchymal stem cells and their clinical applications in osteoarthritis. Cell Transpl 25(5):937-950. https://doi.org/10.3727/096368915X 690288

11. Berman M, Lander E (2017) A prospective safety study of autologous adipose-derived stromal vascular fraction using a specialized surgical processing system. Am J Cosmet Surg 20:17. https ://doi.org/10.1177/0748806817691152

12. Yang Y, Ma T, Ge J, Quan X, Yang L, Zhu S, Huang L, Liu Z, Liu L, Geng D, Huang J, Luo Z (2016) Facilitated neural differentiation of adipose tissue-derived stem cells by electrical stimulation and Nurr-1 gene transduction. Cell Transpl 25(6):1177-1191. https://doi.org/10.3727/096368915X688957

13. Safford KM, Hicok KC, Safford SD, Halvorsen YD, Wilkison WO, Gimble JM, Rice HE (2002) Neurogenic differentiation of murine and human adipose-derived stromal cells. Biochem Biophys Res Commun 294(2):371-379. https://doi.org/10.1016/ S0006-291X(02)00469-2

14. Busser H, Najar M, Raicevic G, Pieters K, Velez Pombo R, Philippart P, Meuleman N, Bron D, Lagneaux L (2015) Isolation and characterization of human mesenchymal stromal cell subpopulations: comparison of bone marrow and adipose tissue. Stem Cells Dev 24(18):2142-2157. https://doi.org/10.1089/ scd.2015.0172

15. Sowa Y, Imura T, Numajiri T, Nishino K, Fushiki S (2012) Adipose-derived stem cells produce factors enhancing peripheral nerve regeneration: influence of age and anatomic site of origin. Stem Cells Dev 21(11):1852-1862. https://doi.org/10.1089/ scd.2011.0403

16. Alio Del Barrio JL, El Zarif M, de Miguel MP, Azaar A, Makdissy N, Harb W, El Achkar I, Arnalich F, Alio JL (2017) Cellular therapy with human autologous adipose-derived adult stem cells for advanced keratoconus. Cornea. https://doi.org/10.1097/ ico.0000000000001228

17. Kantake M, Hirano A, Sano M, Urushihata N, Tanemura H, Oki K, Suzaki E (2017) Transplantation of allogeneic adiposederived mesenchymal stem cells in a cerebral palsy patient. Regen Med. https://doi.org/10.2217/rme-2017-0043

18. Ra JC, Shin IS, Kim SH, Kang SK, Kang BC, Lee HY, Kim YJ, Jo JY, Yoon EJ, Choi HJ, Kwon E (2011) Safety of intravenous infusion of human adipose tissue-derived mesenchymal stem cells in animals and humans. Stem Cells Dev 20(8):1297-1308. https://doi.org/10.1089/scd.2010.0466

19. Smith OJ, Kanapathy M, Khajuria A, Prokopenko M, HachachHaram N, Mann H, Mosahebi A (2017) Protocol for a systematic review of the efficacy of fat grafting and platelet-rich plasma for wound healing. Syst Rev 6(1):111. https://doi.org/10.1186/s1364 3-017-0505-8

20. Lee M, Ban JJ, Yang S, Im W, Kim M (2018) The exosome of adipose-derived stem cells reduces beta-amyloid pathology and apoptosis of neuronal cells derived from the transgenic mouse model of Alzheimer's disease. Brain Res 1691:87-93. https://doi. org/10.1016/j.brainres.2018.03.034

21. Chi K, Fu RH, Huang YC, Chen SY, Hsu CJ, Lin SZ, Tu CT, Chang LH, Wu PA, Liu SP (2018) Adipose-derived stem cells stimulated with n-butylidenephthalide exhibit therapeutic effects in a mouse model of Parkinson's disease. Cell Transpl 27(3):456-470. https://doi.org/10.1177/0963689718757408

22. Ghorabi MT, Aliaghaei A, Sadeghi Y, Shaerzadeh F, Rad AA, Mohamadi R, Ebrahimi JM (2017) Evidence supporting neuroprotective effect of adipose derived stem cells on PC12 cells against oxidative stress induced by $\mathrm{H}_{2} \mathrm{O}_{2}$. Cell Mol Biol (Noisyle-grand) 63(3):1-6. https://doi.org/10.14715/cmb/2017.63.3.1

23. Lee M, Ban JJ, Kim KY, Jeon GS, Im W, Sung JJ, Kim M (2016) Adipose-derived stem cell exosomes alleviate pathology of amyotrophic lateral sclerosis in vitro. Biochem Biophys Res Commun 479(3):434-439. https://doi.org/10.1016/j. bbrc.2016.09.069

24. Bonafede R, Scambi I, Peroni D, Potrich V, Boschi F, Benati D, Bonetti B, Mariotti R (2016) Exosome derived from murine adipose-derived stromal cells: neuroprotective effect on in vitro model of amyotrophic lateral sclerosis. Exp Cell Res 340(1):150-158. https://doi.org/10.1016/j.yexcr.2015.12.009

25. Zack-Williams SD, Butler PE, Kalaskar DM (2015) Current progress in use of adipose derived stem cells in peripheral nerve regeneration. World J Stem Cells 7(1):51-64. https:// doi.org/10.4252/wjsc.v7.i1.51

26. Farinazzo A, Turano E, Marconi S, Bistaffa E, Bazzoli E, Bonetti B (2015) Murine adipose-derived mesenchymal stromal cell vesicles: in vitro clues for neuroprotective and neuroregenerative approaches. Cytotherapy 17(5):571-578. https ://doi.org/10.1016/j.jcyt.2015.01.005

27. Berg J, Roch M, Altschuler J, Winter C, Schwerk A, Kurtz A, Steiner B (2015) Human adipose-derived mesenchymal stem cells improve motor functions and are neuroprotective in the 6-hydroxydopamine-rat model for Parkinson's disease when cultured in monolayer cultures but suppress hippocampal neurogenesis and hippocampal memory function when cultured in spheroids. Stem Cell Rev 11(1):133-149. https://doi. org/10.1007/s12015-014-9551-y

28. Moon SM, Kim W, Chung JY, Im W, Yoo DY, Jung HY, Won MH, Choi JH, Hwang IK (2014) Neuroprotective effects of adipose-derived stem cells are maintained for 3 weeks against ischemic damage in the rabbit spinal cord. Biomed Res Int 2014:539051. https://doi.org/10.1155/2014/539051

29. Kim KS, Lee HJ, An J, Kim YB, Ra JC, Lim I, Kim SU (2014) Transplantation of human adipose tissue-derived stem cells delays clinical onset and prolongs life span in ALS mouse model. Cell Transpl 23(12):1585-1597. https://doi. org/10.3727/096368913X673450

30. Chan TM, Chen JY, Ho LI, Lin HP, Hsueh KW, Liu DD, Chen YH, Hsieh AC, Tsai NM, Hueng DY, Tsai ST, Chou PW, Lin SZ, Harn HJ (2014) ADSC therapy in neurodegenerative disorders. Cell Transpl 23(4-5):549-557. https://doi. org/10.3727/096368914X678445

31. Egashira Y, Sugitani S, Suzuki Y, Mishiro K, Tsuruma K, Shimazawa M, Yoshimura S, Iwama T, Hara H (2012) The conditioned medium of murine and human adipose-derived stem cells exerts neuroprotective effects against experimental stroke model. Brain Res 1461:87-95. https://doi.org/10.1016/j. brainres.2012.04.033

32. Chung JY, Kim W, Im W, Yoo DY, Choi JH, Hwang IK, Won MH, Chang IB, Cho BM, Hwang HS, Moon SM (2012) Neuroprotective effects of adipose-derived stem cells against ischemic neuronal damage in the rabbit spinal cord. J Neurol Sci 317(1-2):40-46. https://doi.org/10.1016/j.jns.2012.02.035

33. Berman S, Uhlendorf TL, Berman M, Lander EB (2018) Effective treatment of traumatic brain injury in Rowett Nude Rats with stromal vascular fraction transplantation. Brain Sci. https ://doi.org/10.3390/brainsci8060112

34. Chernoff G, Bryan N, Park AM (2018) Mesothelial stem cells and stromal vascular fraction: use in functional disorders, wound healing, fat transfer, and other conditions. Facial Plast Surg Clin North Am 26(4):487-501. https://doi.org/10.1016/j. fsc.2018.06.009

35. Zhou L, Song Q, Shen J, Xu L, Xu Z, Wu R, Ge Y, Zhu J, Wu J, Dou Q, Jia R (2017) Comparison of human adipose stromal 
vascular fraction and adipose-derived mesenchymal stem cells for the attenuation of acute renal ischemia/reperfusion injury. Sci Rep 7:44058. https://doi.org/10.1038/srep44058

36. Siennicka K, Zolocinska A, Stepien K, Lubina-Dabrowska N, Maciagowska M, Zolocinska E, Slysz A, Piusinska-Macoch R, Mazur S, Zdanowicz U, Smigielski R, Stepien A, Pojda Z (2016) Adipose-derived cells (stromal vascular fraction) transplanted for orthopedical or neurological purposes: are they safe enough? Stem Cells Int 2016:5762916. https://doi. org/10.1155/2016/5762916

37. Faustini M, Bucco M, Chlapanidas T, Lucconi G, Marazzi M, Tosca MC, Gaetani P, Klinger M, Villani S, Ferretti VV, Vigo D, Torre ML (2010) Nonexpanded mesenchymal stem cells for regenerative medicine: yield in stromal vascular fraction from adipose tissues. Tissue Eng Part C Methods 16(6):1515-1521. https://doi.org/10.1089/ten.TEC.2010.0214

38. Haddad-Mashadrizeh A, Bahrami AR, Matin MM, Edalatmanesh MA, Zomorodipour A, Fallah A, Gardaneh M, Ahmadian Kia N, Sanjarmoosavi N (2013) Evidence for crossing the blood barrier of adult rat brain by human adipose-derived mesenchymal stromal cells during a 6-month period of post-transplantation. Cytotherapy 15(8):951-960. https://doi.org/10.1016/j. jcyt.2013.03.003

39. Oppliger B, Joerger-Messerli M, Mueller M, Reinhart U, Schneider P, Surbek DV, Schoeberlein A (2016) Intranasal delivery of umbilical cord-derived mesenchymal stem cells preserves myelination in perinatal brain damage. Stem Cells Dev 25(16):12341242. https://doi.org/10.1089/scd.2016.0027

40. Bagheri-Mohammadi S, Alani B, Karimian M, Moradian-Tehrani R, Noureddini M (2019) Intranasal administration of endometrial mesenchymal stem cells as a suitable approach for Parkinson's disease therapy. Mol Biol Rep. https://doi.org/10.1007/s1103 3-019-04883-8

41. Li YH, Feng L, Zhang GX, Ma CG (2015) Intranasal delivery of stem cells as therapy for central nervous system disease. Exp Mol Pathol 98(2):145-151. https://doi.org/10.1016/j.yexmp .2015.01.016

42. Jiang Y, Zhu J, Xu G, Liu X (2011) Intranasal delivery of stem cells to the brain. Expert Opin Drug Deliv 8(5):623-632. https ://doi.org/10.1517/17425247.2011.566267

43. Hammadi AM, Al-Himyari FA (2017) Intrathecal injection of peripherally mobilized blood stem cells to treat multiple sclerosis. Exp Clin Transpl 15(Suppl 1):147-149. https://doi. org/10.6002/ect.mesot2016.P26

44. Ommaya AK (1963) Subcutaneous reservoir and pump for sterile access to ventricular cerebrospinal fluid. Lancet 2(7315):983-984

45. Kilinc MO, Santidrian A, Minev I, Toth R, Draganov D, Nguyen D, Lander E, Berman M, Minev B, Szalay AA (2018) The ratio of ADSCs to HSC-progenitors in adipose tissue derived SVF may provide the key to predict the outcome of stem-cell therapy. Clin Transl Med 7(1):5. https://doi.org/10.1186/s4016 9-018-0183-8

46. McIntosh K, Zvonic S, Garrett S, Mitchell JB, Floyd ZE, Hammill L, Kloster A, Di Halvorsen Y, Ting JP, Storms RW, Goh B, Kilroy G, Wu X, Gimble JM (2006) The immunogenicity of human adipose-derived cells: temporal changes in vitro. Stem Cells 24(5):1246-1253. https://doi.org/10.1634/stemc ells.2005-0235

47. Scherberich A, Di Maggio ND, McNagny KM (2013) A familiar stranger: CD34 expression and putative functions in SVF cells of adipose tissue. World J Stem Cells 5(1):1-8. https://doi. org/10.4252/wjsc.v5.i1.1

48. Sengenes C, Lolmede K, Zakaroff-Girard A, Busse R, Bouloumie A (2005) Preadipocytes in the human subcutaneous adipose tissue display distinct features from the adult mesenchymal and hematopoietic stem cells. J Cell Physiol 205(1):114-122. https ://doi.org/10.1002/jcp.20381

49. Kurtzke JF (1983) Rating neurologic impairment in multiple sclerosis: an expanded disability status scale (EDSS). Neurology 33(11):1444-1452

50. Shankle WR, Mangrola T, Chan T, Hara J (2009) Development and validation of the Memory Performance Index: reducing measurement error in recall tests. Alzheimers Dement 5(4):295306. https://doi.org/10.1016/j.jalz.2008.11.001

51. Randolph C, Tierney MC, Mohr E, Chase TN (1998) The repeatable battery for the assessment of neuropsychological status (RBANS): preliminary clinical validity. J Clin Exp Neuropsychol 20(3):310-319. https://doi.org/10.1076/ jcen.20.3.310.823

52. Folstein MF, Folstein SE, McHugh PR (1975) "Mini-mental state". A practical method for grading the cognitive state of patients for the clinician. J Psychiatr Res 12(3):189-198

53. Higgins JJ (2013) Dementia diagnostics: preparing for a pending healthcare epidemic. MLO Med Lab Obs 45(7):52-53

54. Gir P, Oni G, Brown SA, Mojallal A, Rohrich RJ (2012) Human adipose stem cells: current clinical applications. Plast Reconstr Surg 129(6):1277-1290. https://doi.org/10.1097/PRS.0b013 e31824ecae6

55. Yeh DC, Chan TM, Harn HJ, Chiou TW, Chen HS, Lin ZS, Lin SZ (2015) Adipose tissue-derived stem cells in neural regenerative medicine. Cell Transpl 24(3):487-492. https://doi. org/10.3727/096368915X686940

56. Marfia G, Navone SE, Hadi LA, Paroni M, Berno V, Beretta M, Gualtierotti R, Ingegnoli F, Levi V, Miozzo M, Geginat J, Fassina L, Rampini P, Tremolada C, Riboni L, Campanella R (2016) The adipose mesenchymal stem cell secretome inhibits inflammatory responses of microglia: evidence for an involvement of sphingosine-1-phosphate signalling. Stem Cells Dev 25(14):1095-1107. https://doi.org/10.1089/scd.2015.0268

57. Akiyama H, Barger S, Barnum S, Bradt B, Bauer J, Cole GM, Cooper NR, Eikelenboom P, Emmerling M, Fiebich BL, Finch CE, Frautschy S, Griffin WS, Hampel H, Hull M, Landreth G, Lue L, Mrak R, Mackenzie IR, McGeer PL, O’Banion MK, Pachter J, Pasinetti G, Plata-Salaman C, Rogers J, Rydel R, Shen Y, Streit W, Strohmeyer R, Tooyoma I, Van Muiswinkel FL, Veerhuis R, Walker D, Webster S, Wegrzyniak B, Wenk G, Wyss-Coray T (2000) Inflammation and Alzheimer's disease. Neurobiol Aging 21(3):383-421

58. Matchynski-Franks JJ, Pappas C, Rossignol J, Reinke T, Fink K, Crane A, Twite A, Lowrance SA, Song C, Dunbar GL (2016) Mesenchymal stem cells as treatment for behavioral deficits and neuropathology in the 5xFAD mouse model of Alzheimer's disease. Cell Transpl 25(4):687-703. https://doi.org/10.3727/09636 8916X690818

59. Lucchinetti CF, Popescu BF, Bunyan RF, Moll NM, Roemer SF, Lassmann H, Bruck W, Parisi JE, Scheithauer BW, Giannini C, Weigand SD, Mandrekar J, Ransohoff RM (2011) Inflammatory cortical demyelination in early multiple sclerosis. N Engl J Med 365(23):2188-2197. https://doi.org/10.1056/NEJMoa1100648

60. Collins-Praino LE, Arulsamy A, Katharesan V, Corrigan F (2018) The effect of an acute systemic inflammatory insult on the chronic effects of a single mild traumatic brain injury. Behav Brain Res 336:22-31. https://doi.org/10.1016/j.bbr.2017.08.035

61. Tang BL (2017) The use of mesenchymal stem cells (MSCs) for amyotrophic lateral sclerosis (ALS) therapy-a perspective on cell biological mechanisms. Rev Neurosci. https://doi. org/10.1515/revneuro-2017-0018

62. Iwasa SN, Babona-Pilipos R, Morshead CM (2017) Environmental factors that influence stem cell migration: an "electric field". Stem Cells Int 2017:4276927. https://doi. org/10.1155/2017/4276927 
63. Wu JH, Li M, Liang Y, Lu T, Duan CY (2016) Migration of adipose-derived mesenchymal stem cells stably expressing chondroitinase ABC in vitro. Chin Med J (Engl) 129(13):1592-1599. https://doi.org/10.4103/0366-6999.184464

64. Horwitz EM, Prockop DJ, Fitzpatrick LA, Koo WW, Gordon PL, Neel M, Sussman M, Orchard P, Marx JC, Pyeritz RE, Brenner MK (1999) Transplantability and therapeutic effects of bone marrow-derived mesenchymal cells in children with osteogenesis imperfecta. Nat Med 5(3):309-313. https://doi.org/10.1038/6529

65. Liu X, Ye R, Yan T, Yu SP, Wei L, Xu G, Fan X, Jiang Y, Stetler RA, Liu G, Chen J (2014) Cell based therapies for ischemic stroke: from basic science to bedside. Prog Neurobiol 115:92115. https://doi.org/10.1016/j.pneurobio.2013.11.007

66. Argibay B, Trekker J, Himmelreich U, Beiras A, Topete A, Taboada P, Perez-Mato M, Vieites-Prado A, Iglesias-Rey R, Rivas J, Planas AM, Sobrino T, Castillo J, Campos F (2017) Intraarterial route increases the risk of cerebral lesions after mesenchymal cell administration in animal model of ischemia. Sci Rep 7:40758. https://doi.org/10.1038/srep40758

67. Fauzi AA, Suroto NS, Bajamal AH, Machfoed MH (2016) Intraventricular transplantation of autologous bone marrow mesenchymal stem cells via ommaya reservoir in persistent vegetative state patients after haemorrhagic stroke: report of two cases \& review of the literature. J Stem Cells Regen Med 12(2):100-104

68. Jozwiak S, Habich A, Kotulska K, Sarnowska A, Kropiwnicki T, Janowski M, Jurkiewicz E, Lukomska B, Kmiec T, Walecki J, Roszkowski M, Litwin M, Oldak T, Boruczkowski D, Domanska-Janik K (2010) Intracerebroventricular transplantation of cord blood-derived neural progenitors in a child with severe global brain ischemic injury. Cell Med 1(2):71-80. https://doi. org/10.3727/215517910X536618

69. Luan Z, Yin GC, Hu XH, Qu SQ, Wu NH, Yan FQ, Qian YM, Jin HY, Gong XJ (2005) Treatment of an infant with severe neonatal hypoxic-ischemic encephalopathy sequelae with transplantation of human neural stem cells into cerebral ventricle. Zhonghua Er Ke Za Zhi 43(8):580-583 (discussion 580)

70. Baek W, Kim YS, Koh SH, Lim SW, Kim HY, Yi HJ, Kim H (2012) Stem cell transplantation into the intraventricular space via an Ommaya reservoir in a patient with amyotrophic lateral sclerosis. J Neurosurg Sci 56(3):261-263

71. Ra J-CK, Kim Y-Y, Kim E-Y (2017) Effect of the multiple intravenous administration of cultured human autologous adiposederived stem cells on tumor biomarker levels. J Clin Case Rep 7(11): 1040

72. Marconi S, Bonaconsa M, Scambi I, Squintani GM, Rui W, Turano E, Ungaro D, D'Agostino S, Barbieri F, Angiari S, Farinazzo A, Constantin G, Del Carro U, Bonetti B, Mariotti R (2013) Systemic treatment with adipose-derived mesenchymal stem cells ameliorates clinical and pathological features in the amyotrophic lateral sclerosis murine model. Neuroscience 248:333-343. https://doi.org/10.1016/j.neuroscien ce.2013.05.034

73. Bonafede R, Mariotti R (2017) ALS pathogenesis and therapeutic approaches: the role of mesenchymal stem cells and extracellular vesicles. Front Cell Neurosci 11:80. https://doi.org/10.3389/fncel .2017 .00080

74. Shakhbazau A, Potapnev M (2016) Autologous mesenchymal stromal cells as a therapeutic in ALS and epilepsy patients: treatment modalities and ex vivo neural differentiation. Cytotherapy 18(10):1245-1255. https://doi.org/10.1016/j.jcyt.2016.06.001

75. Sun H, Benardais K, Stanslowsky N, Thau-Habermann N, Hensel N, Huang D, Claus P, Dengler R, Stangel M, Petri S (2013) Therapeutic potential of mesenchymal stromal cells and MSC conditioned medium in amyotrophic lateral sclerosis (ALS)-in vitro evidence from primary motor neuron cultures, NSC-34 cells, astrocytes and microglia. PLoS ONE 8(9):e72926. https:// doi.org/10.1371/journal.pone.0072926

76. Mazzini L, Vercelli A, Ferrero I, Boido M, Cantello R, Fagioli F (2012) Transplantation of mesenchymal stem cells in ALS. Prog Brain Res 201:333-359. https://doi.org/10.1016/B978-0444-59544-7.00016-0

77. Mazzini L, Vercelli A, Mareschi K, Ferrero I, Testa L, Fagioli F (2009) Mesenchymal stem cells for ALS patients. Amyotroph Lateral Scler 10(2):123-124. https://doi.org/10.1080/17482 960802572707

78. Forostyak S, Sykova E (2017) Neuroprotective potential of cell-based therapies in ALS: from bench to bedside. Front Neurosci 11:591. https://doi.org/10.3389/fnins.2017.00591

79. Staff NP, Madigan NN, Morris J, Jentoft M, Sorenson EJ, Butler G, Gastineau D, Dietz A, Windebank AJ (2016) Safety of intrathecal autologous adipose-derived mesenchymal stromal cells in patients with ALS. Neurology 87(21):2230-2234. https ://doi.org/10.1212/WNL.0000000000003359

80. Forostyak S, Homola A, Turnovcova K, Svitil P, Jendelova P, Sykova E (2014) Intrathecal delivery of mesenchymal stromal cells protects the structure of altered perineuronal nets in SOD1 rats and amends the course of ALS. Stem Cells 32(12):3163-3172. https://doi.org/10.1002/stem.1812

81. Knippenberg S, Thau N, Dengler R, Brinker T, Petri S (2012) Intracerebroventricular injection of encapsulated human mesenchymal cells producing glucagon-like peptide 1 prolongs survival in a mouse model of ALS. PLoS ONE 7(6):e36857. https://doi.org/10.1371/journal.pone.0036857

82. Zhao CP, Zhang C, Zhou SN, Xie YM, Wang YH, Huang H, Shang YC, Li WY, Zhou C, Yu MJ, Feng SW (2007) Human mesenchymal stromal cells ameliorate the phenotype of SOD1G93A ALS mice. Cytotherapy 9(5):414-426. https://doi. org/10.1080/14653240701376413

83. Habisch HJ, Janowski M, Binder D, Kuzma-Kozakiewicz M, Widmann A, Habich A, Schwalenstocker B, Hermann A, Brenner R, Lukomska B, Domanska-Janik K, Ludolph AC, Storch A (2007) Intrathecal application of neuroectodermally converted stem cells into a mouse model of ALS: limited intraparenchymal migration and survival narrows therapeutic effects. J Neural Transm (Vienna) 114(11):1395-1406. https://doi. org/10.1007/s00702-007-0748-y

84. Ma T, Gong K, Ao Q, Yan Y, Song B, Huang H, Zhang X, Gong Y (2013) Intracerebral transplantation of adiposederived mesenchymal stem cells alternatively activates microglia and ameliorates neuropathological deficits in Alzheimer's disease mice. Cell Transpl 22(Suppl 1):S113-S126. https://doi. org/10.3727/096368913X672181

85. Kim S, Chang KA, Kim J, Park HG, Ra JC, Kim HS, Suh YH (2012) The preventive and therapeutic effects of intravenous human adipose-derived stem cells in Alzheimer's disease mice. PLoS ONE 7(9):e45757. https://doi.org/10.1371/journ al.pone. 0045757

86. Harach T, Jammes F, Muller C, Duthilleul N, Cheatham V, Zufferey V, Cheatham D, Lukasheva YA, Lasser T, Bolmont $\mathrm{T}$ (2017) Administrations of human adult ischemia-tolerant mesenchymal stem cells and factors reduce amyloid beta pathology in a mouse model of Alzheimer's disease. Neurobiol Aging 51:83-96. https://doi.org/10.1016/j.neurobiola ging.2016.11.009

87. Katsuda T, Oki K, Ochiya T (2015) Potential application of extracellular vesicles of human adipose tissuederived mesenchymal stem cells in Alzheimer's disease therapeutics. Methods Mol Biol 1212:171-181. https://doi. org/10.1007/7651_2014_98

88. Liew LC, Katsuda T, Gailhouste L, Nakagama H, Ochiya T (2017) Mesenchymal stem cell-derived extracellular vesicles: a 
glimmer of hope in treating Alzheimer's disease. Int Immunol. https://doi.org/10.1093/intimm/dxx002

89. Lehrer S, Rheinstein PH (2015) Is Alzheimer's disease autoimmune inflammation of the brain that can be treated with nasal nonsteroidal anti-inflammatory drugs? Am J Alzheimers Dis Other Demen 30(3):225-227. https://doi.org/10.1177/15333 17514545478

90. McCarthy M (2014) NIH will partner drug industry to study Alzheimer's, diabetes, and autoimmune disorders. BMJ 348:g 1397. https://doi.org/10.1136/bmj.g1397

91. D'Andrea MR (2005) Add Alzheimer's disease to the list of autoimmune diseases. Med Hypotheses 64(3):458-463. https ://doi.org/10.1016/j.mehy.2004.08.024

92. Nasiri E, Alizadeh A, Roushandeh AM, Gazor R, HashemiFirouzi N, Golipoor Z (2019) Melatonin-pretreated adiposederived mesenchymal stem cells efficeintly improved learning, memory, and cognition in an animal model of Alzheimer's disease. Metab Brain Dis. https://doi.org/10.1007/s11011-01900421-4

93. Reza-Zaldivar EE, Hernandez-Sapiens MA, Minjarez B, Gutierrez-Mercado YK, Marquez-Aguirre AL, Canales-Aguirre AA (2018) Potential effects of MSC-derived exosomes in neuroplasticity in Alzheimer's disease. Front Cell Neurosci 12:317. https://doi.org/10.3389/fncel.2018.00317

94. Yamazaki H, Jin Y, Tsuchiya A, Kanno T, Nishizaki T (2015) Adipose-derived stem cell-conditioned medium ameliorates antidepression-related behaviors in the mouse model of Alzheimer's disease. Neurosci Lett 609:53-57. https://doi. org/10.1016/j.neulet.2015.10.023

95. Yan Y, Ma T, Gong K, Ao Q, Zhang X, Gong Y (2014) Adipose-derived mesenchymal stem cell transplantation promotes adult neurogenesis in the brains of Alzheimer's disease mice. Neural Regen Res 9(8):798-805. https://doi.org/10.4103/16735374.131596

96. Ha S, Ahn S, Kim S, Joo Y, Chong YH, Suh YH, Chang KA (2014) In vivo imaging of human adipose-derived stem cells in Alzheimer's disease animal model. J Biomed Opt 19(5):051206. https://doi.org/10.1117/1.JBO.19.5.051206

97. Chang KA, Kim HJ, Joo Y, Ha S, Suh YH (2014) The therapeutic effects of human adipose-derived stem cells in Alzheimer's disease mouse models. Neurodegener Dis 13(2-3):99-102. https://doi.org/10.1159/000355261

98. Sugaya K, Alvarez A, Marutle A, Kwak YD, Choumkina E (2006) Stem cell strategies for Alzheimer's disease therapy. Panminerva Med 48(2):87-96

99. Ragerdi Kashani I, Hedayatpour A, Pasbakhsh P, Kafami L, Atlasi N, Pirhajati Mahabadi V, Mamoudi R, Baazm M (2012) 17beta-Estradiol enhances the efficacy of adipose-derived mesenchymal stem cells on remyelination in mouse model of multiple sclerosis. Acta Med Iran 50(12):789-797

100. Al Jumah MA, Abumaree MH (2012) The immunomodulatory and neuroprotective effects of mesenchymal stem cells (MSCs) in experimental autoimmune encephalomyelitis (EAE): a model of multiple sclerosis (MS). Int J Mol Sci 13(7):92989331. https://doi.org/10.3390/ijms13079298

101. Wootla B, Eriguchi M, Rodriguez M (2012) Is multiple sclerosis an autoimmune disease? Autoimmune Dis 2012:969657. https://doi.org/10.1155/2012/969657

102. Abdallah AN, Shamaa AA, El-Tookhy OS (2019) Evaluation of treatment of experimentally induced canine model of multiple sclerosis using laser activated non-expanded adipose derived stem cells. Res Vet Sci 125:71-81. https://doi.org/10.1016/j. rvsc.2019.05.016

103. Bowles AC, Strong AL, Wise RM, Thomas RC, Gerstein BY, Dutreil MF, Hunter RS, Gimble JM, Bunnell BA (2017) Adipose stromal vascular fraction-mediated improvements at late-stage disease in a murine model of multiple sclerosis. Stem Cells 35(2):532-544. https://doi.org/10.1002/stem.2516

104. Bowles AC, Wise RM, Gerstein BY, Thomas RC, Ogelman R, Manayan RC, Bunnell BA (2018) Adipose stromal vascular fraction attenuates TH1 cell-mediated pathology in a model of multiple sclerosis. J Neuroinflamm 15(1):77. https://doi. org/10.1186/s12974-018-1099-3

105. Cobo M, Anderson P, Benabdellah K, Toscano MG, Munoz P, Garcia-Perez A, Gutierrez I, Delgado M, Martin F (2013) Mesenchymal stem cells expressing vasoactive intestinal peptide ameliorate symptoms in a model of chronic multiple sclerosis. Cell Transpl 22(5):839-854. https://doi.org/10.3727/09636 8912X657404

106. Darlington PJ, Boivin MN, Bar-Or A (2011) Harnessing the therapeutic potential of mesenchymal stem cells in multiple sclerosis. Expert Rev Neurother 11(9):1295-1303. https://doi. org/10.1586/ern.11.113

107. Fernandez O, Izquierdo G, Fernandez V, Leyva L, Reyes V, Guerrero M, Leon A, Arnaiz C, Navarro G, Paramo MD, Cuesta A, Soria B, Hmadcha A, Pozo D, Fernandez-Montesinos R, Leal M, Ochotorena I, Galvez P, Geniz MA, Baron FJ, Mata R, Medina C, Caparros-Escudero C, Cardesa A, Cuende N, Research Group Study Eudra CT (2018) Adiposederived mesenchymal stem cells (AdMSC) for the treatment of secondary-progressive multiple sclerosis: a triple blinded, placebo controlled, randomized phase I/II safety and feasibility study. PLoS ONE 13(5):e0195891. https://doi.org/10.1371/ journal.pone.0195891

108. Giacoppo S, Bramanti P, Mazzon E (2017) The transplantation of mesenchymal stem cells derived from unconventional sources: an innovative approach to multiple sclerosis therapy. Arch Immunol Ther Exp (Warsz) 65(5):363-379. https://doi. org/10.1007/s00005-017-0460-z

109. Hedayatpour A, Ragerdi I, Pasbakhsh P, Kafami L, Atlasi N, Pirhajati Mahabadi V, Ghasemi S, Reza M (2013) Promotion of remyelination by adipose mesenchymal stem cell transplantation in a cuprizone model of multiple sclerosis. Cell $\mathrm{J}$ 15(2):142-151

110. Laso-Garcia F, Ramos-Cejudo J, Carrillo-Salinas FJ, OteroOrtega L, Feliu A, Gomez-de Frutos M, Mecha M, Diez-Tejedor E, Guaza C, Gutierrez-Fernandez M (2018) Therapeutic potential of extracellular vesicles derived from human mesenchymal stem cells in a model of progressive multiple sclerosis. PLoS ONE 13(9):e0202590. https://doi.org/10.1371/journ al.pone. 0202590

111. Stepien A, Dabrowska NL, Maciagowska M, Macoch RP, Zolocinska A, Mazur S, Siennicka K, Frankowska E, Kidzinski R, Chalimoniuk M, Pojda Z (2016) Clinical application of autologous adipose stem cells in patients with multiple sclerosis: preliminary results. Mediat Inflamm 2016:5302120. https ://doi.org/10.1155/2016/5302120

112. Hoyer C, Eisele P, Ebert AD, Schneider S, Gass A, Fatar M, Szabo K, Alonso A (2016) Blood-CSF-barrier dysfunction is a marker for encephalitic involvement in patients with aseptic meningitis/meningoencephalitis. J Clin Virol 84:82-86. https ://doi.org/10.1016/j.jcv.2016.10.006

113. Alonso A, Eisele P, Ebert AD, Griebe M, Engelhardt B, Szabo K, Hennerici MG, Gass A (2015) Leptomeningeal contrast enhancement and blood-CSF barrier dysfunction in aseptic meningitis. Neurol Neuroimmunol Neuroinflamm 2(6):e164. https://doi.org/10.1212/NXI.0000000000000164

114. Simard PF, Tosun C, Melnichenko L, Ivanova S, Gerzanich V, Simard JM (2011) Inflammation of the choroid plexus and ependymal layer of the ventricle following intraventricular hemorrhage. Transl Stroke Res 2(2):227-231. https://doi. org/10.1007/s12975-011-0070-8 
115. Liu DZ, Sharp FR (2012) Excitatory and mitogenic signaling in cell death, blood-brain barrier breakdown, and BBB repair after intracerebral hemorrhage. Transl Stroke Res 3(Suppl 1):62-69. https://doi.org/10.1007/s12975-012-0147-z

116. Liu DZ, Ander BP, Xu H, Shen Y, Kaur P, Deng W, Sharp FR (2010) Blood-brain barrier breakdown and repair by Src after thrombin-induced injury. Ann Neurol 67(4):526-533. https:// doi.org/10.1002/ana.21924

117. Hwang PH, Jackler RK (1996) Lipoid meningitis due to aseptic necrosis of a free fat graft placed during neurotologic surgery. Laryngoscope 106(12 Pt 1):1482-1486
118. Ricaurte JC, Murali R, Mandell W (2000) Uncomplicated postoperative lipoid meningitis secondary to autologous fat graft necrosis. Clin Infect Dis 30(3):613-615. https://doi. org/10.1086/313732

Publisher's Note Springer Nature remains neutral with regard to jurisdictional claims in published maps and institutional affiliations.

\section{Affiliations}

\section{Christopher Duma ${ }^{1}$ (D) Oleg Kopyov ${ }^{1} \cdot$ Alex Kopyov $^{1} \cdot$ Mark Berman $^{2} \cdot$ Elliot Lander ${ }^{2} \cdot$ Michael Elam $^{2}$. Michael Arata ${ }^{2}$. David Weiland ${ }^{3} \cdot$ Ruslana Cannell $^{4}$. Chad Caraway ${ }^{4} \cdot$ Sean Berman ${ }^{2} \cdot$ Kristin Scord $^{1} \cdot$ Lian Stemler $^{1}$. Karlyssa Chung ${ }^{1}$. Samuel Khoudari ${ }^{1}$. Rory McRory ${ }^{1}$. Chace Duma ${ }^{1}$. Sawyer Farmer ${ }^{1}$. Anthony Bravo ${ }^{1}$. Christian Yassa ${ }^{1} \cdot$ Ami Sanathara $^{1} \cdot$ Elisa Singh ${ }^{1}$. Benjamin Rapaport ${ }^{1}$}

Oleg Kopyov

okopyov@cellavie.com

Alex Kopyov

akopyov@cellavie.com

Mark Berman

mark@cellsurgicalnetwork.com

Elliot Lander

elliot@cellsurgicalnetwork.com

Michael Elam

info@michaelelammd.com

Michael Arata

marata@drarata.com

David Weiland

djweilan@uci.edu

Ruslana Cannell

rcannell@uci.edu

Chad Caraway

ccaraway@uci.edu

Sean Berman

sean@cellsurgicalnetwork.com

Kristin Scord

kscordpac@newportbeachdps.com

Lian Stemler

1stemler@stanford.edu

Karlyssa Chung

kchung@brainandspineoc.com
Samuel Khoudari

samuel.khoudari@hoag.org

Rory McRory

rmccrory@brainandspineoc.com

Chace Duma

chaceduma@ucsb.edu

Sawyer Farmer

shfarmer@ucsd.edu

Anthony Bravo

aabravo@uci.edu

Christian Yassa

cyassa123@berkeley.edu

Ami Sanathara

sanathaa@coyote.csusb.edu

Elisa Singh

elisa.singh@hoag.org

Benjamin Rapaport

brapaport@brainandspineoc.com

1 Neurosurgery, Brain and Spine Surgeons of Orange County, Newport Beach, CA, USA

2 Cell Surgical Network, Los Angeles, CA, USA

3 School of Medicine, University of California - Irvine, Irvine, CA, USA

4 Department of Neurobiology, University of California - Irvine, Irvine, CA, USA 